\title{
Pengaruh Self-Efficacy Terhadap Kepatuhan Dalam Pembatasan Cairan Pada Pasien Ginjal Kronik Yang Menjalani Hemodialisa Di RSUD Yogyakarta
}

Sugiarto1 Rian Tasalim2 SaktyaYudha Ardhi Utama 3

1,3 Universitas Alma Ata Yogyakarta, 2 Universitas Sari Mulia Banjarmasin

Email:sugiarto@almaata.ac.id 085877181819

\section{DOI: $10.33859 / \mathrm{dksm.v11i1.534}$}

\begin{abstract}
Abstrak
Latar Belakang: Gagal ginjal kronis adalah suatu penyakit yang terjadi akibat dari rusaknya fungsi ginjal baik secara keseluruhan ataupun sebagian, dampak dari penyakit gagal ginjal yaitu kelebihan volume cairan, cara yang baik untuk meminimalkan volume cairan pada tubuh yaitu dengan cara patuh terhadap pembatasan cairan.
\end{abstract}

Tujuan : tujuan dalam penelitian ini yaitu untuk mengetahui self-efficacy dalam pembatasan cairan pada pasien gagal ginjal kronik

Metode: Metode penelitian yang digunakan pada penelitian ini adalah quasi eksperiment dengan desain penelitian deskriptif kuantitatif. Tehnik pengambilan sampel menggunakan purposive sampling, populasi dalam penelitian ini sebanyak 105 responden dengan jumlah sampling 30 responden analisa uji paired sample $t$-test dengan menggunakan uji wilcoxon.

Hasil Penelitian: hasil penelitian menunjukan self-efficacy dalam pembatasan cairan pada pasien gagal ginjal kronik bahwa dalam katagori tidak patuh sebanyak 16 responden (48\%), sedangkan sebanyak 14 responden yang patuh (42\%). Hal tersebut dikarenakan responden self effecy diri yang rendah dengan 17 responden atau ( 51\%) sangat yakin dan sebanyak 13 responden atau sebayak (49\%) sehingga kepatuhan dalam mengikuti perintah yang kurang baik dan tingkat keperdulihan terhadap penyakitnya yang kurang maksimal dengan nilai p-value 0,323 .

Kesimpulan Kesimpulan dalam penelitian ini menunjukkan tidak adanya pengaruh yang signifikan anatara self-efficacy dengan kepatuhan pembatasan cairan.

Kata Kunci :Self-efficacy, Kepatuhan, Pembatasan Cairan, Pasien Ginjal Kronik. 


\begin{abstract}
Background: Chronic renal failure is a disease that occurs as a result of the breakdown of renal function either in whole or in part, the impact of the disease of renal failure i.e. excess fluid volume, a good way to minimize the volume of fluid The body by adherence to fluid restriction.

Objectives: The purpose in this research is to know the self-efficacy in the restriction of fluid in patients with chronic renal failure

Methods:The research method used in this study is a quasi experiment with quantitative descriptive research design. The sampling technique uses purposive sampling, the population in this study was 105 respondents with a total sampling of 30 respondents analyzed the paired sample $t$-test using the Wilcoxon test.

Research results: the results showed self-efficacy in limiting fluid in patients with chronic renal failure that in the category of non-compliance were 16 respondents (48\%), while as many as 14 respondents were compliant (42\%). That is because low self-efficacy respondents with 17 respondents or (51\%) are very confident and as many as 13 respondents or equal (49\%) so that compliance in following orders is not good and the level of recovery from the disease is less than the maximum value of p-value .323.

The conclusions in this study indicate that there is no significant effect between self-efficacy and adherence to fluid restriction.
\end{abstract}

Keywords: Self-efficacy, compliance, fluid restriction, chronic kidney patients.

\section{PENDAHULUAN}

Penyakit ginjal kronik merupakan suatu penyakit yang disebabkan oleh rusaknya ginjal yang dapat menurunkan fungsi ginjal yang bersifat progresif dan irrevesibel dengan atau tanpa penurunan LFG (lajufiltrasi glomerulus) yang ditandai adanya penurunan jumlah urine, abnormalitas komposisi darah dan LFG dengan nilai<60 ml/menit/1,73 m yang berlangsung lebih dari 3 bulan (Pernerfi,2016). Hemodialisis adalah salah satu terapi pengganti ginjal yang menggunakan alat ginjal buatan yaitu dialyzer untuk menyaring dan membuang sisa metabolism berupa toksin yang seharusnya dibuang oleh ginjal (Pernerfi,2016). Hemodialisis merupakan salah satu terapi pengganti ginjal yang paling banyak digunakan selain peritoneal dialysis dan tranplantasi ginjal (Haryanti, 2015)

Akibat dari ketidak mampuan ginjal untuk membuang produk sisa metabolism melalui urine dan dapat menyebabkan gangguan endokrin, metabolik dan cairan elektrolit serta asam basa, sehingga diperlukanya tindakan hemodialisis atau transplantasi ginjal untuk kelangsungan hidup pasien (Faradisa, et al, 2016).

Di Negara Amerika Serikat, kejadian prevalensi penyakit gagal ginjal mengalami 
peningkatan dan jumlah orang yang gagal ginjal yang dirawat dengan dilakukan tindakan dialysis \& transplantasi diproyeksikan meningkat dari 390.000 di tahun 1992, dan 651.000 dalam tahun 2010. Data tersebut menunjukkan bahwa setiap tahun mengalami peningkatan, 200.000 orang Amerika menjalani hemodialisa dikarenkan mengalami gangguan ginjal kronisartinya 1140 dalam 1 juta orang Amerika adalah pasien dialisis. Sedangkan di negara Malaysia, dengan populasi 18 juta, diperkirakan terdapat 1800 kasus baru gagal ginjal pertahunnya (Neliya, 2012).

Di dunia, sekitar 2.622.000 orang telah menjalani pengobatan End - Stage Renal Disease (ESRD) pada akhirtahun 2010, sebanyak 2.029 .000 orang (77\%) diantaranya menjalan ipengobatan dialisis dan 593.000 orang $(23 \%)$ menjalani transplantasi ginjal. Gagal ginjal terjadi di Indonesia, setiap tahunnya dalam katagori tinggi karena dapat dilihat dari banyak masyarakat Indonesia tidak mampu menjaga pola makan dan kesehatan tubuhnya. Hasil survey yang dilakukan PERNEFRI (Perhimpunan Nefrologi Indonesia) pada tahun 2009, prevalensi gagal ginjal kronik di Indonesia sekitar 12,5\% berarti sekitar 18 juta orang dewasa di Indonesia menderita penyakit gagal ginjal kronik (Neliya, 2012).

Pembatasan asupan cairan pada pasien gagal ginjal kronik yang menjalani hemodialisa merupakan hal yang utama dan sangat penting untuk diperhatikan, karena asupan cairan yang berlebihan dapat mengakibatkan kenaikan berat badan, edema, bronchi basah dalam paru - paru, kelopak mata yang bengkak dan sesak nafas yang diakibatkan oleh volume cairan yang berlebihan. Cairan yang diminum pasien yang menjalani hemodialisa harus diawasi dengan seksama. Beberapa pasien mengalami kesulitan dalam membatasi asupan cairan yang masuk, namun mereka tidak mendapatkan pemahaman tentang bagaimana strategi yang dapat membantu mereka dalam pembatasan cairan (Tovazzi\&Mazzoni, 2012). Meskipun pasien sudah mengerti bahwa kegagalan dalam pembatasan cairan dapat berakibat fatal, namun sekitar $50 \%$ pasien yang menjalani terapi hemodialisis tidak mematuhi pembatasan cairan yang direkomendasikan (Barnett, Li, Pinikahana \& Si, 2007).

Manajemen pembatasan cairan dan makanan berdampak terhadap penambahan IDWG. Oleh karenaitu IDWG dianggap sebagai ukuran kepatuhan pasien yang menjalani terapi hemodialisis. Ketidak mampuan pasien untuk mengikuti diet CKD dipengaruhi oleh keyakinan diri atau selfefficacy yang rendah. Pasien memerlukan edukasi dan komunikasi yang efektif sehingga pasien dapat meningkatkanself-efficacy untuk mempertahankan IDWG dalam batas normal. Penerapannya melalui edukasi terstruktur yang dilakukan secara terprogram dan sistematis 
Dinamika Kesehatan Jurnal Kebidanan dan Keperawatan Vol 11 No. 1 Juli 2020 ( ISSN: 2086-3454 EISSN: 2549-4058)

url: http://ojs.dinamikakesehatan.unism.ac.id DOI : https://doi.org/10.33859/dksm.v11il

Pengaruh Self-Efficacy Terhadap Kepatuhan Dalam Pembatasan Cairan Pada Pasien Ginjal Kronik Yang Menjalani Hemodialisa Di RSUD Yogyakarta

serta didukung dengan metode tertentu yang dibutuhkan pasien. Intervensi edukasi tersebut diharapkan mampu meningkatkan self efficacy positif pada pasien HD dalam mempertahankan IDWG, terutama keyakinan dalam membatasi intake cairan.

\section{METODE}

Metode penelitian yang digunakan pada penelitian ini adalah kuasi eksperimen dengan desain penelitian pre-test and post-test without the control group.Tehnik pengambilan sampel menggunakan purposive sampling dengan jumlah responden105 berdasarkan kreteria inkusi dan exklusi dalam penelitian ini yaitu 30 responden yang dijadikan sebagai subjek penelitian analisa uji paired sample $t$ test dengan menggunakan uji wilcoxon.

Metode penelitian ini adalah kuantitatif dengan menggumpulkan data primer. Desain penelitian yang digunakan adalah semiexperimental dimana variable independen dan dependen diamati secara bersamaan. Populasi adalah pasien dengan penyakit ginjal kronik yang menjalani Hemodialisa rutin 2 kali seminggu baik yang menderita Hemodialisa 1 tahun ataupun 2 tahun yang tercatat di buku Rekam Medik Pasien RSUD Kota Yogyakarta. Penentuan sampel terpilih menggunakan metode Purposive sampling. Metode purposive sampling memerlukan nama pasien yang menderita penyakit ginjal kronik,umur pasien,lama menderita Hemodialisa. Untuk besar sampel yang didapatkan sebesar 30 sampel. Kriteria eksklusi adalah pasien yang tidak mengikuti jalannya penelitian sampai selesai dan inklusi sampel adalah pasien penyakit ginjal kronik yang menjalani hemodilasis rutin 2 kali seminggu.

Jenis data yang dikumpulkan meliputi data karakteristik subjek penelitian menggunkan kuesioner tersetruktur, data selfefficacy pada pasien hemodialisa menggunkan kuesioner yang diadopsi dari penelitian pratiwi (2015) telah dimodifikasi yang sebelumnya diuji pakar dengan ahli di bidangnya yang telah menempuh Strata 2, data pembatasan cairan dihitung menggunakan lembar pengukuran IDWG subjek penelitian. Data yang diperoleh kemudian diolah menggunakan statistic univariat dan bivariate. Analisi sspearmen rank digunakan untuk melihat hubungan self efficacy dan kepatuhan pembatasan cairan pada pasien ginjal kronik yang menjalani hemdialisa di RSUD Kota Yogyakarta.

Pertimbangan etika penelitian digunakan untuk memastikan bahwa responden dilindungi dengan memperhatikan aspek self determination, privacy and dignity, anonimity and confidentiality,informed consent dan protection from discomfort (Polit \& Beck, 1994). Meskipun penelitian ini tidak ada resiko yang merugikan baik terhadap responden, RSUD Kota Yogyakarta maupun peneliti, tetapi prinsip-prinsip etik tetap ditegakkan. 
Dinamika Kesehatan Jurnal Kebidanan dan Keperawatan Vol 11 No. 1 Juli 2020 ( ISSN: 2086-3454 EISSN: 2549-4058)

url: http://ojs.dinamikakesehatan.unism.ac.id DOI : https://doi.org/10.33859/dksm.v11i1

Pengaruh Self-Efficacy Terhadap Kepatuhan Dalam Pembatasan Cairan Pada Pasien Ginjal Kronik Yang Menjalani Hemodialisa Di RSUD Yogyakarta

\section{HASIL}

Karakteristik subjek penelitian

Tabel 1. Karakteristik Sampel

\begin{tabular}{lll}
\hline $\begin{array}{l}\text { Karakteristik } \\
\text { Responden }\end{array}$ & $\begin{array}{l}\text { Frekuen } \\
\text { si(f) }\end{array}$ & Presentase(\%) \\
\hline Umur & & \\
$18-39$ & 6 & $19.3 \%$ \\
$40-65$ & 23 & $69.9 \%$ \\
$>65$ & 4 & $10.8 \%$ \\
\hline Jenis Kelamin & & \\
Laki-laki & 17 & $51.4 \%$ \\
Perempuan & 13 & $49.6 \%$ \\
\hline Tingkat Pendidikan & & \\
Tidak sekolah & 2 & $6 \%$ \\
SD & 3 & $9 \%$ \\
SMP & 5 & $15 \%$ \\
SMA & 12 & $36.0 \%$ \\
S1 & 8 & $34 \%$ \\
\hline Lama HD & & \\
$<1$ Tahun & 4 & $12 \%$ \\
$>1$ Tahun & 26 & $78 \%$ \\
& 30 & $100 \%$
\end{tabular}

Jumlah 30

Hasil penelitian tentang karakteristik responden berdasarkan umur menunjukkan bahwa sebagian besar responden dengan rentang 40-60 tahun sebanyak 58 responden (69.9\%), sedangkan berusia kurangdari 40 tahunsebanyak 6 responden $(10.8 \%)$. Hasil penelitian tentang karakteristik responden berdasarkan jenis kelamin menunjukkan sebagian besar responden berjenis kelamin laki-laki sebanyak 17 (54.5\%), sedangkan sebagian kecil berjenis kelamin perempuan sebanyak 13 responden (44.6\%).

Hasil penelitian tentang karakteristik responden berdasarkan pedidikan menunjukkan bahwa sebagian besar responden berpendidikan SMA sebanyak 12 responden (36\%), sedangkan sebagian tidak bersekolah sebanyak 2 responden (6\%).
Hasil penelitian tentang karakteristik responden berdasarkan lama HD menunjukkan bahwa responden memiliki lama HD >1 tahunsebanyak 26 responden (78\%), sedangkans <1 tahunsebanyak 4 responden $(12 \%)$.

Tabel 2. Tingkat Self-efficacy pada Pasien Penyakit Ginjal Kronik yang menjalani HD di RSUD Kota Yogyakarta.

\begin{tabular}{lll}
\hline Self efficacy & Frekuensi & Persentase \\
\hline Sangat Yakin & 17 & $51 \%$ \\
\hline Tidak yakin & 13 & $49 \%$ \\
\hline Total & 30 & $100 \%$ \\
\hline
\end{tabular}

Berdasarkan hasil pengumpulan dan pengolahan data penelitian ini tentang tingkat self-efficacy pada pasien Ginjal Kronik yang menjalani hemodialisa di RSUD Kota Yogyakarta memiliki self-efficacy sangat yakin sebanyak 17 responden $(51 \%)$ dan self efficacy tidakyakinsebanyak 13 responden $(49 \%)$.

Menurut Yuni, 2016 semakin tinggi nilai self-efficacy seseorang maka kepatuhan dalam melakukan pembatasan cairan semakin baik. Hal ini dikarenakan subjek dengan self efficacy skor yang tinggi karena lama menjalani hemodialisis sedangkan kepatuhannya dalam membatasi cairan tidak patuh karena tidak mampu membatasi konsumsi cairan dan makanan selama hemodialisa.

Hal ini dibuktikan pada pasien HD dengan lama menjalani hemodialisa lebih dari 1 tahun saat proses hemodialisa berlangsung 
Dinamika Kesehatan Jurnal Kebidanan dan Keperawatan Vol 11 No. 1 Juli 2020 ( ISSN: 2086-3454 EISSN: 2549-4058)

url: http://ojs.dinamikakesehatan.unism.ac.id DOI : https://doi.org/10.33859/dksm.v11i1

Pengaruh Self-Efficacy Terhadap Kepatuhan Dalam Pembatasan Cairan Pada Pasien Ginjal Kronik Yang Menjalani Hemodialisa Di RSUD Yogyakarta

sebagian pasien sering mengkonsumsi makanan dan minuman(Suwitra, 2014).

Efikasi diri sebagai teori social kognitif pada tahun 1977 didefinisikan sebagai keyakinan yang menentukan bagaimana seseorang berfikir, memotivasi dirinya dan bagaimana akhirnya memutuskan untuk melakukan sebuah perilaku untuk mencapai tujuan yang diinginkan. Dimensi efikasi diri ada 3 menurut Bandura yaitu magnitude, generality dan strength (Rahman 2013).

Penelitian Coringan, 2011 tentang self - efficacy dengan kepatuhan pembatasan cairan pada pasiengagalginjalkronik yang menjalani hemodialisis di RSUD Panembahan Senopati Bantul menunjukkan self- efficacy tinggi 25 orang $(69,4 \%)$, dan pasien yang patuh dalam membatasi cairan sebanyak 22 orang $(61,1 \%)$. Hal ini menunjukkan bahwa terdapat komunikasi dan pemecahan masalah dihadapi dengan positif, sehingga keluarga dan klien mempunyai keyakinan diri untuk sembuh.

Tabel 3. Kepatuhan Pembatasan Cairan pada Pasien Penyakit Ginjal Kronik yang menjalani HD di RSUD Kota Yogyakarta

\begin{tabular}{lll}
\hline $\begin{array}{l}\text { Kepatuhan } \\
\text { Pembatasan cairan }\end{array}$ & Frekuensi & $\begin{array}{l}\text { Persentase } \\
(\%)\end{array}$ \\
\hline Patuh & 14 & $42 \%$ \\
\hline Tidak Patuh & 16 & $48 \%$ \\
\hline Total & 30 & $100 \%$
\end{tabular}

Berdasarkan hasil pengumpulan dan pengolahan data penelitian ini tentang kepatuhan pembatasan cairan pada pasien penyakit ginjal kronik yang menjalani HD di RSUD Kota Yogyakarta dalam katagori patuh
14 responden (42\%), sedangkan sebanyak 16 responden tidak patuh sebanyak (38\%). Hal tersebut dikarenakan responden self effecy diri yang rendah sehingga kepatuhan dalam mengikuti perintah yang kurangbaik. Pembatasan cairan pada pasien penyakit ginjal kronik yang menjalani hemodialisa merupakan hal yang sangat penting untuk diperhatikan, karena asupan cairan yang berlebihan dapat mengakibatkan kenaikan berat badan, edema, bronchitis, kelopak mata bengkak, dan sesaknafas, yang diakibatkan oleh volume cairan yang berlebihan.Cairan yang diminumpasien yang menjalani hemodialisa harus diawasi dengan seksama. Beberapa pasien mengalami kesulitan dalam membatasi cairan yang masuk, namun mereka tidak mendapatkan pemahaman tentang bagaimana strategi yang dapat membantu mereka dalam pembatasan cairan (Setiti, 2014)

Beberapa penelitian menunjukkan 60$80 \%$ pasien meninggal akibat ketidak patuhan dalam pembatasan cairan sehingga kelebihan masukan cairan dan makanan pada periode interdialitik. Penelitian lainnya menyebutkan bahwa pembatasan cairan sangat sulit bagi pasien terdapat $60.7 \%$ tidak mematuhi pembatasancairan, sehingga perlu mendapatkan edukasi dan konseling secara rutin dan berkelanjutan. 
Dinamika Kesehatan Jurnal Kebidanan dan Keperawatan Vol 11 No. 1 Juli 2020 ( ISSN: 2086-3454 EISSN: 2549-4058) url: http://ojs.dinamikakesehatan.unism.ac.id DOI : https://doi.org/10.33859/dksm.v11il

Pengaruh Self-Efficacy Terhadap Kepatuhan Dalam Pembatasan Cairan Pada Pasien Ginjal Kronik Yang Menjalani Hemodialisa Di RSUD Yogyakarta

Tabel 4. Analisa bivariat pengaruh self-efficacy dengan kepatuhan pembatasan cairan pada pasien penyakit ginjal kronik yang menjalani hemodialisa di RSUD Kota Yogyakarta

\begin{tabular}{lllllll}
\hline & \multicolumn{4}{l}{$\begin{array}{l}\text { Kepatuhan } \\
\text { Self- } \\
\text { efficacy }\end{array}$} & \multicolumn{3}{l}{ Pembatasan Cairan } & P & \\
\cline { 2 - 5 } & Patuh & \multicolumn{3}{c}{$\begin{array}{l}\text { Tidak } \\
\text { patuh }\end{array}$} & & \\
\cline { 2 - 5 } & $\mathrm{N}$ & $\%$ & $\mathrm{~N}$ & $\%$ & & \\
\hline $\begin{array}{l}\text { Sangat } \\
\text { Yakin }\end{array}$ & 17 & 51 & 16 & 42 & 33 & 0.323 \\
\hline $\begin{array}{l}\text { Tidak } \\
\text { yakin }\end{array}$ & 13 & 49 & & 48 & 27 & \\
\hline Total & $100 \%$ & & & & & \\
\hline
\end{tabular}

Berdasarkan table diatas dapat dilihat bahwa paling banyak responden memiliki self tidak yakin dengan kecenderungan memiliki tidak patuh dalam membatasi cairan sebanyak 17 responden $(51 \%)$ dan self-efficacy sangat yakin sebanyak dengan patuh terhadap pembatasan cairan sebanyak 34 responden (49\%). Berdasarkan penelitian ini diperoleh kesignifikanan Self-efficacy dengan Kepatuhan Pembatasan cairan pada Pasien Penyakit Ginjal Kronik yang menjalani hemodialisa di RSUD Kota Yogyakarta sebesar 0.001 dan nilai $\mathrm{p}$ value sebesar $0323<$ 0.05. Dari hasil tersebut bahwa dapat disimpulkan bahwa tidak ada pengaruh antara Self-efficacy dengan kepatuhan pembatasan cairan pada pasien penyakit ginjal kronik yang menjalani hemodialisa di RSUD Kota Yogyakarta. Semakin tinggi Self-efficacy seseorang maka semakin tidak patuh dalam membatasi cairan

Menurut Sulistyaningsih (2012), penting bagi pasien penyakit ginjal kronik yang menjalani hemodialisis untuk meningkatkan efikasi diri dalam mematuhi regimen perawatan diri, karena hal ini diperlukan untuk menentukan sebuah tindakan atau tidak.

\section{KESIMPULAN}

Sebagian besar responden dalam penelitian ini berusia 40-65 dengan prevalensi pasien laki-laki sebesar 69,9\% dan pasien perempuan sebanyak 49,6\%. Prevalensi selfefficacy sangat yakin sebanyak 53\%. Tingkat kepatuhan pembatasan cairan di dominasi pada tidak patuh sebanyak $48 \%$. Kesimpulan dalam penelitian ini menunjukkan tidak ada pengaruh yang signifikanan atara self-efficacy dengan kepatuhan pembatasan cairan.

\section{Daftar pustaka}

Faradisayuanita al ell.,Gambaran Self Care Status Cairan Pada Pasien Hemodialisa ( Literatur Review ) Jurnal Care Vol. 4, No.2, Tahun 2016

Neliya, S.W (2012) Hubungan pengetahuan tentang asupan cairan dan pengendalian asupan cairan terhadap penambahan berat badan. Jurnal nursing studies

Barnett, T., Li, Y.T., Pinikahana, J., Si, Y.T. (2007). Fluid Compliance among Patients Having Hemodialysis: Can An Educational Programme Make A Difference, journal of advanced nursing, 61 (3), 300-306. 
Haryanti, I, A. P., \&Nisa, K. Terapi Konservatif dan Terapi Pengganti Ginja sebagai Penatalaksanaan pada Gagal Ginjal Kronik. Majority . Volume 4. Nomor 7. Juni 2015

Beck, C. T. (1994). Phenomenology: Its use in nursing research. International Journal Nursing, 31, 499-510.

Pratiwi D. A. (2015). Hubungan Dukungan Keluarga Dengan Tingkat Depresi Pasien Gagal Ginjal Kronik Dengan Hemodialisis di RS PKU Muhammadiyah Yogyakarta. Skripsi. STIKES 'Aisyiyah Yogyakarta

Abdul Rahman, Agus. 2013. PsikologiSosial: Integrasi Pengetahuan Wahyu dan Pengetahuan Empirik. Jakarta: Rajawali Pers.

Setiati S, Alwi I, Sudoyo AW, Stiyohadi B, Syam AF. Buku ajar ilmu penyakit dalam jilid I. VI. Jakarta: Interna Publishing; 2014:1132-53.

Sulistyaningsih. (2012). Metodologi Penelitian Kebidanan Kuantitatif-Kualitatif. Yogyakarta: Grahallmu

Suwitra K. Penyakit ginjal kronik. In: Setiati S, editor. Ilmu penyakit dalam. 6th ed. Jakarta: Interna Publishing; 2014. p. 2161-67

Tovazzi, ME \&Mazzoni V. (2012). Personal Paths Of Fluid Setriction In Patient On Hemodalysis, Nephrologi Nursing Journal

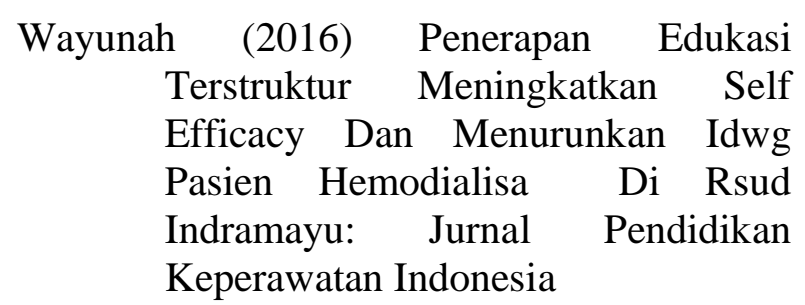

